Nebojša Petrović

Univerzitet u Beogradu

npetrovi@f.bg.ac.rs

ORCID 0000-0002-1623-4018

Aleksandra Lazić

Univerzitet u Beogradu

aleksandra.lazic@f.bg.ac.rs

ORCID: 0000-0002-0433-0483

\title{
Između zvanične istine i ličnog sećanja: Usmene istorije civila i vojnika o post- -jugoslovenskim ratovima 1991-1995
}

\begin{abstract}
Petrović Nebojša, Lazić Aleksandra, Između zvanične istine i ličnog sećanja: Usmene istorije civila i vojnika o post-jugoslovenskim ratovima 1991-1995 (Between Official Truth and Personal Memory: Oral Histories of Civilians and Soldiers in the Post-Yugoslav Wars 1991-1995). "Poznańskie Studia Slawistyczne" 16. Poznań 2019. Publishing House of the Poznań Society for the Advancement of the Arts and Sciences, Adam Mickiewicz University, pp. 227-241. ISSN 2084-3011.

In times of violent conflicts, societies tend to promote narratives that enable successful coping with the situation. Official collective memory can thus provide foundation for a group's belonging, mobilization, persistence. On the other hand, it often perpetuates the animosity by, for example, delegitimizing (and often dehumanizing) the other side. In this article, we explore whether unofficial personal memories of a violent conflict could mitigate the damage in intergroup relations done by the dominating narratives. We conducted a secondary thematic analysis of 38 interviews with civilians and soldiers in the Post-Yugoslav wars (1991-1995). The themes we report here offer deeply personal and humanizing accounts of the war experience, which have largely remained outside traditional historiography.
\end{abstract}

KEYwORDs: oral history; post-Yugoslav wars; reconciliation; rehumanization; collective memory; thematic analysis

\section{Uvod}

Sećanja na bitne istorijske događaje nikada nisu tačna beleška tih događaja, poput fotografije, video zapisa ili fajla sačuvanog na računaru. Ona su uvek, i na ličnom i na društvenom nivou, rekonstrukcija onog što 
se dogodilo, sa nenamernim i namernim oduzimanjima i pridavanjima dodatnih elemenata.

Već na samom početku psihologije kao samostalne naučne discipline, niz autora je jasno pokazao da su naša sećanja veoma krhka i nestabilna (Ebbinghaus, 1885/1913; Bartlett, 1932), te da se lako menjaju ne samo po kvantitetu (tako što pamtimo sve manje informacija), nego i po kvalitetu (tako što recimo manje poznato zamenjujemo poznatijim). Takva gledišta su uglavnom potvrđena i u nizu novijih istraživačkih paradigmi, poput pristupa kognitivne obrade informacija (Loftus, 1979) i motivisanog sećanja (Kunda, 1990), kao trajne tendencije ljudi da razmišljaju na način koji produkuje zaključke konzistentne njihovim željama.

Na društvenom nivou, jedan od najvećih i najznačanijih svetskih pokušaja da se pamćenje i svedočenje o zlodelima koja su se dogodila iskoriste kao lekovito sredstvo za podeljeno društvo takođe se sudario sa problemom šta je istina i šta se tačno zbilo tokom perioda aparthejda u Južnoafričkoj Republici (Truth and Reconciliation Commission of South Africa Report, 1998). U svojoj knjizi Zemlja zderane maske (Boraine, 2000), jedan od najznačajnijih članova Komisije govori o čak četiri vrste distinktivnih istinâ: forenzičkoj, ličnoj ili narativnoj, društvenoj i isceljujućoj istini (u drugim verzijama - ličnoj, društvenoj, ljudskoj i univerzalnoj). Ovo je tema koja zahteva velike i brojne naučne radove, a za naš rad je pre svega značajno da istina o proteklim događajima, čak i o onima gde su savremenici još živi, često nije jedne vrste, kao i da se razne vrste istina mogu unekoliko i sukobljavati. Razloga za to je mnogo i o tome je dosta pisano (npr. Halbwachs, 1980; Neisser, 1982; Petrović, 2007; László, 2013), a mi ćemo se u ovom radu fokusirati na lična sećanja ljudi, sudionika i savremenika jedne istorijske epohe, sličnosti pamćenja običnih ljudskih sudbina i međusobne sličnosti onog što se dogodilo i što je proživljeno nezavisno od pripadnosti određenoj etničkoj grupi.

Čovek funkcioniše na više nivoa i ono što pamti jeste deo onoga što on jeste. Kao što je socijalni identitet deo ličnog identiteta, i socijalno pamćenje jeste važan aspekt svake pojedine osobe. Ono što će osoba zapamtiti je ono što je procesuirano kroz njenu percepciju i nije potpuno podudarno sa stvarnošću. Međutim, kod kolektivnih sećanja javljaju se i brojne namerne manipulacije zbog važnosti sećanja kako za identitet neke grupe, tako i za političke borbe koje uzimaju formu takmičenja u mobilizaciji i kontroli mogućnosti u okviru političkog i socijalnog diskursa (Baker, 1985). Tako 
neke ideje dobijaju važnije mesto u odnosu na ostale u određenim društvima i u određenim istorijskim razdobljima.

Pomenuti psiholog Bartlet je pokazao da i proces i sadržaj sećanja pojedinca jesu dominantno uslovljeni socijalnim uticajima kao što su kultura, interesi, društveni običaji, institucionalna praksa i grupni identitet. Grupe sa društvenom moći ,postavljaju scenu i usmeravaju akcije“ u percipiranju, predstavljanju i pamćenju kroz medije, obrazovanje, kulturne i druge produkte.

Dakle, određeni pogledi i određene ,istine“ postaju zajednička sećanja velike većine članova društva, ponekad i ako se nisu dogodila, nego su indukovana podsticanjem iz različitih domena života kao što su politika, ekonomija, religija, kultura, itd. Takva sećanja između ostalog definišu identitet grupe i obezbeđuju racionalizaciju za osećaj pripadanja grupi (Bar-Tal, 2000). Zato su ona očigledno značajna i u svakodnevnoj realnosti članova društva jer utiču na njihove poglede i akcije, što počinje da se tretira kao deo političke kulture.

Politička kultura je legitimna i često se tiče ideja o slobodi, o ljudskim pravima i sličnom, ali tokom i nakon sukoba, posebno onih koju su dugi, iscrpljujući i sa puno žrtava, čitav ovaj kompleks se potpuno degeneriše. Kolektivna sećanja svake strane u sukobu daju sliku tog sukoba koja je u skladu sa potrebama date strane (Cairns, Roe, 2003; Halbwachs, 1980). Takvi narativi imaju nekoliko važnih tema koje negativno utiču na percepciju sukoba i njegovo rešenje, jer su jednostrane i selektivne te služe potrebama članova društva da gledaju na sebe kao na pravične, humane i moralne. Pored toga, u sećanjima grupe ostaje i herojstvo i nevini gubici i patnje svojih članova, a surovost onih drugih i slično. Ovo se dalje potkrepljuje u udžbenicima, patriotskoj literaturi, filmovima, i tako postaje sve prisutnije i značajnije u glavama pojedinih ljudi, članova drušva, uključujući tu i nove generacije koje rat i nisu doživele. Prošlost se preoblikuje i prilagođava da služi aktuelnim potrebama i stavovima članova društva. Međutim, ljudi su, u isto vreme, i nezavisni pojedinci, sa svojim posebnim ličnim iskustvom i sopstvenim zapažanjima sveta oko sebe. Ko onda pobeđuje u toj borbi - lično i doživljeno ili društveno i preneto?

U psihologiji postoji više modela kojima se pokazuje kako ljudi u različitim momentima i domenima mogu koristiti alternativne psihološke puteve radi dostizanja određenog cilja. Jedan od poznatijih modela jeste 
model obrade informacija koji može biti centralni, usmeren na činjenice, i periferni, usmeren na pogodne znake, heuristike (Petty, Cacioppo, 1986). Ljudi, takođe, u teškim, neizvesnim i stresnim trenucima ističu socijalni identitet, dok u drugačijim okolnostima ističu svoju specifičnost i jedinstvenost (npr. Tajfel, Turner, 1986). Analogno tome, izgleda da ljudi kako u području intergrupnih odnosa, tako i u području korišćenja ličnih ili grupnih narativa mogu koristiti iste taktike. U jednoj anegdotskoj epizodi iz istraživanja grupnih odnosa između Srba i Hrvata u Vukovaru, istraživači su primetili da se oni jedni drugima javljaju i raspituju za to kako su kada se susretnu samostalno, ali ne i kada su u društvu još nekog pripadnika svoje grupe. Očito je da ljudi u javnim raspravama - u nastupima gde se vide ili smatraju predstavnicima svoje grupe - govoreći o nečemu, posebno o ratnom iskustvu, najčešće postupaju kao primeran učenik koji želi da što preciznije reprodukuje naučenu lekciju, u ovom slučaju zvaničnu, etabliranu istinu svoje strane. Sasvim je drugačije kada su stavljeni u situaciju da govore kao pojedinci, kao ljudi sa jedinstvenim ličnim iskustvom, i kada su oslobođeni opasnosti da budu ocrnjeni kao izdajnici sopstvene grupe. Pozicija ispitanika u usmenim istorijama omogućava baš to i zato nosi veliki potencijal za savladavanje prepreka iz teške prošlosti.

Izvor podataka biće nam 38 detaljnih polustrukturisanih intervjua iz edicije Ljudi u ratu (Gojković, Bašić, Delić, 2003, 2004; Gojković, Bašić, 2004a, 2004b; Gojković, 2005). Intervjui su vođeni sa ljudima iz Srbije, Hrvatske i Bosne i Hercegovine, od kojih su neki bili regrutovani ili su se dobrovoljno javili u vojne jedinice, dok su drugi bili civili, iz ratom više ili manje zahvaćenih područja, koji su proživeli rat u svojim kućama ili su prognani. Među ispitanicima je bilo i žena i muškaraca, i starijih i mlađih, a razlikuje se i njihova socijalna situacija nakon rata - neki su osiromašeni i u privremenim smeštajima, drugi su cenjeni kao žrtve ili heroji rata u svojoj sredini, a treći su nastavili svoj život u inostranstvu (jedan od autora ovog rada je vodio intervjue sa oko petnaest osoba koje su se trajno skrasile u Beču). Intervjui su nastali tokom perioda između 1998. i 2004. godine, manje od decenije nakon sukoba, u želji da se utvrdi kako se neposredni učesnici i svedoci ratnih stradanja u prvoj polovini 90-ih sećaju tih događaja i kako ih doživljavaju. Važna karakteristika ovih intervjua jeste u tome što kroz pažljivo konstruisana pitanja, odnosno teme razgovora, ispitanike usmeravaju da sa ličnog stanovišta opišu svoja sećanja na date 
događaje, svoja osećanja i dileme u tim trenucima, svoje viđenje uzroka i toka događaja, kao i perspektive za budućnost. Ti pogledi su, kako smo pokazali, nesumnjivo pod uticajem i socijalnog sistema u kome ljudi žive i grupa kojima pripadaju, ali ipak postoji i deo potpuno lične ispovesti koja je nevidljiva u zvaničnoj istoriji i najčešće nepoznata drugim ljudima, bilo iz sopstvene, bilo i iz tuđe grupe. Upravo ova činjenica jeste izvanredno važna za uspostavljanje zajedničkog sistema uverenja, za razumevanje realno postojeće bliskosti po mnogim bitnim ličnim osobinama koje su van dominirajućih razgraničavajućih karakteristika, a time i za građenje zajedničke budućnosti. Ona se svakako lakše može graditi sa nekima koji su doživljavali slične patnje i imali iste, univerzalne ljudske dileme i strahove tokom perioda sukoba, nego sa nekima koji su sušta suprotnost našoj grupi. Čitajući o ličnim iskustvima ljudi sa druge strane linije, čak i onima koji su nosili oružje ili sa kojima smo se gledali preko cevi, dolazimo do nekih podataka na koje ne možemo naići nigde u zvaničnoj istoriji. Sâmo suočavanje sa iskustvima ljudi sa druge strane, a koja su neočekivano slična našim iskustvima, razara pažljivo politički i ideološki građene brane između nas i njih (Pettigrew, Tropp, 2006; Cakal, Petrović, 2017) i uklanja najvažnije prepreke na putu pomirenju koje su se nalazile u viđenju druge grupe kao jedinstvene, drugačije, dehumanizovane i preteće. Uvid da su mnogi među bivšim neprijateljima prolazili kroz slične tegobne trenutke kao i članovi naše grupe, da je i kod njih bilo strahova, dilema, opiranja, isto koliko i posvećenosti borbi i spremnosti za žrtvovanje, neumitno dovodi do otapanja društveno konstruisanih razlika, kao i do rehumanizacije te druge strane (npr. Petrović, 2007; Bar-Tal, Rosen, 2009).

Pored ovoga, po nama najznačajnijeg efekta usmenih istorija kojima se podriva socijetalno veštački konstruisana granica između ljudi i manihejska podela na nas, ispravne i moralne, i na njih, loše i zle, ovo je i značajno svedočanstvo o tome kako čovek, kada se nađe u presudnim trenucima istorije sam sa sobom, reaguje u situaciji koja daleko prevazilazi njegove moći i kako pokušava da opstane u strašnom cunamiju istorijskih nemira. Ta svedočanstva mogu biti veliki i moćan podsticaj i umetnicima za stvaranje uticajnih dela kojima će to preneti široj publici, kao protivtežu zvaničnoj istoriji.

Za razliku od nekih drugih značajnih projekata, uključujući i one koji se bave istim događajima (poput REKOM-a [Kostovicova, 2016], koji pre 
svega traga za svedočenjem žrtava i svedočenjem o najgnusnijim zločinima, što je od nesumnjive vrednosti), ovaj pristup je opštiji, zahvata veoma različite učesnike i svedoke sa posve različitim iskustvima i sudbinama. Tako, sa stanovišta pojedinca, daje delove slike o čitavoj jednoj epohi, o ljudskim stremljenjima, patnjama i nadama u tom periodu kroz specifične detalje i iskustva, prenoseći atmosferu iz mikrokosmosa jednog od značajnih istorijskih događaja.

Da bismo pokazali snagu usmenih istorija, i specifičnost i značaj ličnih doživljaja prošlosti u odnosu na zvaničnu istinu, izvršili smo tematsku analizu datih intervjua i izdvojili šest tema kroz koje se vidi bitnost ličnih sećanja.

\section{Analiza usmenih istorija}

\subsection{Tema: Razočaranost}

Gotovo svi učesnici u ratu ističu da su tokom rata osećali rastuće razočaranje.

Jedan oblik razočaranja se tiče međunarodne zajednice, vlasti i političara, kao i institucije vojske. Ispitanici navode kako su se nadali da će međunarodna zajednica reagovati i da neće dopustiti da dođe do eskalacije oružanih sukoba. Posebno je dominantno osećanje izdaje, prevarenosti, izneverenosti i izigranosti od strane vlasti i političara. Par učesnika u ratu navodi i kako su se razočarali u vojsku svoje države i u svoje saborce. Navode da su im iznevereni ideali i očekivanja koja su ranije imali o toj instituciji, što je posebno prouzrokovano svedočenjima kriminalnom i nemoralnom ponašanju ili nepotrebnoj i preteranoj surovosti prema civilima: „Nadao sam se potajno da ne rade takve stvari, da tu ima neke vrste ideala [...] Onda ti shvatiš da zapravo ti s tim ljudima nemaš ništa [...] da su oni tu da bi pljačkali““ (Ratovanja 2, 56) ${ }^{1}$.

Donekle u vezi sa nemogućnošću poistovećivanja sa saborcima iz vojske i sa nerazumevanjem njihovih postupaka je i opštije razočaranje u ljude

${ }^{1}$ Odavde pa nadalje će se na knjige iz edicije Ljudi u ratu referisati preko naslova, radi preglednosti i lakšeg snalaženja. 
oko sebe - u kolege, komšije, bliske prijatelje. Ispitanici često ističu da su mnogi, ne samo državni moćnici, već i obični ljudi, profitirali tokom rata.

Pored toga, ispitanici opisuju nagle promene koje su uočili kod ljudi oko sebe. Bilo im je posebno neshvatljivo i uznemirujuće kada su se prekidale veze između dotadašnjih bliskih prijatelja i rođaka, kao i kada su se članovi njihove zajednice okretali protiv nekoga samo zato što su pripadali drugoj etničkoj ili religioznoj skupini: „Ja sam imô jako puno Srba prijateljâ prije rata i svi su me ostavili““ (Ratovanja 2, 82); „Mi smo, ono, i zajedno odrasli, u istoj sredini, iste stvari voljeli, iste stvari mrzili [... al ' mi onda nije jasno da on ode i onda, recimo, puca po ovom gradu“" (Ratovanja 2, 179).

Ovakvo razočaranje zbog naglog prekida ili promene socijalnih odnosa navode ne samo učesnici u ratu, već i civilne svedokinje rata. One pri tome često ističu svoju zatečenost i uplašenost kada su primetile da mladi ljudi ispoljavaju ekstremnije stavove: „Tako da je meni bilo jako neshvatljivo, taj rez koji je postojao između moje porodice i te porodice [...] Mama nije niti izjavila saučešće svojoj prvoj rodici“ (Govore žene, 21); „S tim sam ja momcima radila tih godina u toj mojoj firmi, oni su naoružani do zuba, oni moji vozaći [...] Samo što sam 'vako gledala, ja sam vikala, o, moj bože, ima li te đe, šta!“ (Govore žene, 66).

Učesnici u ratu opisuju i sve veći gubitak motivisanosti za ratovanje, a, na kraju, i odustanje od ratovanja, koje je bilo izazvano rastućim razočaranjem u način na koji se rat odvijao. Ističu kako su počinjali da primećuju besmisao rata; u jednom trenutku više ne bi videli svrhu pogibije velikog broja ljudi sa bilo koje strane i ukazalo bi im se da su se ciljevi rata, koje su smatrali opravdanim, izvitoperili. Primetili bi da rat „,ne vodi ničemu“ (Ratovanja 1, 6), da od rata „nema ništa“ (Ratovanja 1, 33), da se sve „okrenulo tumbe“ (Ratovanja 1, 103): „Ja sam mislio da se borimo za nešto pozitivno [...]. A kad sam kasnije vidio sav besmisao, ko je odjednom veliki Srbin, ko rukovodi, šta se radi, ja sam se povukô" (Ratovanja 1, 107); „Kako je vrijeme odmicalo [...] ja sam se totalno razočarao [...]. To je sve nekako učmalo bilo, neorganizovano, nesistematično [...] mladost sva je sarajevska izginula, jer su išli bez oružja“" (Ratovanja 2, 85).

Učesnici u ratu su osećali bes jer su oko njih ljudi ginuli zbog loših uslova, u ratu bez perspektive. Kod dela učesnika, ovakav bes ih je nagonio da pokušaju da zaustave stradanja: „Zbog čega taj čovjek mora biti 
mrtav, ili to dijete, ta žena [...]. I sav je bijes bio usmjeren ka zaustavljanju tog ludila“" (Ratovanja 2, 14).

Sem besa, kao jednu od čestih reakcija u vezi sa razočaranjem učesnici u ratu navode i gubitak patriotskih osećanja. Tokom samih sukoba, patriotizam bi im se „sve više topio“ (Ratovanja 1, 30), splasnuo bi „poslije pet mjeseci“" (Ratovanja 2, 125).

\subsection{Tema: Prisiljenost i nemoć}

Veliki broj ispitanika navodi kako su imali osećaj da im je rat bio nametnut i da im je bila oduzeta sloboda pri donošenju odluka. Osećali su se kao da su bili prisilno ubačeni u nezaustavljivi „,vrtlog“ rata (Ratovanja 1, 112), naterani „u pakao sami“ (Ratovanja 2, 93): „Država ti nametne rat i ti si tu [...] topovsko meso i ništa više“ (Ratovanja 1, 8); „Prvo sam rekâ neću u taj rat $[\ldots]$ Došâ sam u taj rat, onda sam rekâ $[\ldots]$ neću napadat [...] Međutim, na kraju sam došâ i da sam napadâ srpsko selo. A uvik ono, uhvati te mašina i krenete" (Ratovanja 3, 4).

Neki ispitanici opisuju tadašnju represivnu atmosferu koja im je ograničavala slobodu mišljenja. Takođe, ističu da rat nije bio odluka običnih ljudi, „koji se nisu mnogo pitali“ (Ratovanja 1, 136): „Na svakom koraku čovjek je morao gutati. Nije smio reć. Ako je rekao išta što je bilo kontra onoga što je zvanično mišljenje, odmah je bio etiketiran kao jugonostalgičar ili četnik“ (Govore žene, 116); „Mi smo do kraja govorili, nećemo sukob i nećemo sukob! [...]. A ko je narod pitao?" (Govore žene, 87).

Pored nezustavljivosti i represivnosti rata, učesnici u ratu navode i da su često bili prisiljeni da ostanu u vojsci, kao i da im je bila ograničena sloboda kretanja. Na primer, nije im dozvoljavano odsustvo jer je smatrano da se ne bi vratili (Ratovanja 1, 166); a restriktivnost kretanja je bila realnost i van vojske: „Živiš u obruču deset kilometara sa pet“ (Ratovanja 2, 40).

Ratnici ističu i da su često držani u neznanju, „kao zadnji neki kotačići u tom mehanizmu“" (Ratovanja 3, 75); da su im izdavane samo naredbe, bez dovoljno drugih informacija. Nesnađenosti u takvim situacijma je doprinosilo i to što su mnogi bili mladi i bez vojničkog iskustva: „Ne znam u stvari ni pravi razlog zašto sam išao tamo“ (Ratovanja 1, 74); „Čuvaš nešto, a ne znaš ni šta čuvaš““ (Ratovanja 2, 55). 
$\mathrm{Na} \mathrm{kraju,} \mathrm{ispitanici} \mathrm{navode} \mathrm{da} \mathrm{su} \mathrm{se} \mathrm{osećali} \mathrm{nevažno} \mathrm{i} \mathrm{beznačajno;} \mathrm{ose-}$ ćali su „totalnu nemoć“ da se izbore za ono što su smatrali ispravnim.: „Dođeš tu da budeš niko i ništa, nekakav broj, po lageru kojega samo premeću s mjesta na mjesto, bez da te išta pita, ništa ne možeš sam da odrediš “ (Govore žene, 123)

Jedan ispitanik u izgnanstvu navodi kako u ratu ne važe ljudska prava - nikakvi mehanizmi ne štite pojedinca od nasilja (Ratovanja 1, 142, 143): „Ne možete vi tražiti prava kad neko uperi pušku u vas i kaže - idete, šta možete, da se suprotstavite, izgubiti glavu odma' ili reći, idem, pa možda i neću da poginem“ (Ratovanja 1, 142).

Iz ovakvog doživljaja gubitka kontrole nad sopstvenim životom verovatno proističe i to što su mnogi ispitanici davali značaj uplivu spoljašnjih, nekontrolabilnih faktora, kao što su luda sreća, sudbina, igra slučaja, viša sila. Ispitanici često naglašavaju da su samo sticajem srećnih okolnosti bili na pravom mestu u pravo vreme, izbegli ranjavanje ili smrt, našli se među dobrim ljudima: ,Ja nemam čime da se branim [...]. Ako je namjenjeno da moja porodica preživi, ona će preživiti, ako ne bude namjenjeno, neće ni preživjeti“" (Govore žene, 5).

\subsection{Tema: Neverica i konfuzija}

U odgovorima ispitanika preovladava prisećanje na mentalnu konfuziju, zbunjenost i izgubljenost u kojoj su se nalazili, posebno u samim počecima rata. Mnogi su isprva čak i odbijali mogućnost da će doći do rata te su potiskivali emocije straha. Mogućnost rata im je bila „neprihvatljiva zdravom razumu“ (Sudbine civila 1,3) i previše strašna da bi u nju poverovali. Nisu verovali ili nisu hteli da veruju da će doći do rata, „da će doći baš do toga najgorega“ (Ratovanja 1, 68): „Ne može to bit ovdje kod nas u Sarajevu, ma kakvi. Gori, čovječe, sve! Ja gledam televiziju i govorim ne može!"“ (Ratovanja 2, 153).

Bilo im je „nestvarno“ i ,neshvatljivo“ da će rat zahvatiti i njihov grad (Sudbine civila 1,34); na početku nisu pridavali značaja vestima o sukobima, imali su utisak da se sve to odigrava „kao negde tamo“ (Sudbine civila 1, 102): „Ne možeš jednostavno povjerovati da će ti rat pokucati na vrata" (Ratovanja 2, 202). 
Jednom kada bi im došlo do svesti da je rat zaista počeo, doživljavali bi intenzivan šok i bilo im je "sasvim nerazumno da to može da traje“ (Sudbine civila 1, 6).

Neki ispitanici navode da im je bilo nezamislivo da se $u$ to vreme, u Evropi, pristupa nasilnom rešavanju problema. Motivi za rat su im bili nedokučivi i suludi; nisu mogli da shvate, ,šta su im ta djeca skrivila“ (Sudbine civila, 36). Rat opisuju kao ,zvijerski“ (Govore žene, 113-114) i kao „vraćanje unazad“ (Ratovanja 2, 181); niko se nije nadao „baš tol'kom zlu“ (Ratovanja 2, 40). Takođe izražavaju i nevericu da je rat zahvatio područje na kome su ljudi različitih identiteta bili odavno međusobno uvezani. Političke, etničke i nacionalne podele su im delovale nezamislivo.

„Ja nisam uopšte mogla [...] da zamislim kako je moguće izvesti neko ratovanje na prostoru gdje ljudi žive zajedno, gdje se zajedno žene, gdje su familije izmešane“" (Sudbine civila, 3 ).

Ispitanici opisuju da nisu mogli da izađu na kraj sa informacijama koje im tada prenosili mediji. Usled nejasnosti i kontradiktornosti vesti, nisu mogli da izgrade koherentnu sliku onoga što se dešava niti da predvide šta će se desiti sledeće. Osećali su se dezorijentisano i nisu znali kom kanalu informacija da veruju: „Pokušavala sam da pratim neka zbivanja kroz medije, al' sve je to bilo tako nejasno [...]. K'o naučna fantastika. Nisam uopće shvatala šta se događa“" (Sudbine civila 1, 1-2).

Zbog ovakve zbunjenosti, zatečenosti i nesnađenosti, često su se vodili onim što radi većina i tragali su za spoljašnjim autoritetom koji bi im objasnio šta treba da rade: „Neko stanje gdje jednostavno uopšte ne možeš da razmišljaš ti sam [...]. Za tom masom ideš ljudî. Pokušavaš da i ti radiš nešto što ti neko kaže“" (Sudbine civila 1, 50); „Sve se to nekako dešavalo po inerciji. Tako se ulazi upravo u rat [...]. Zbunjen si bio, malo je bilo tu i te euforije" (Ratovanja 2, 92).

\subsection{Tema: Apsurdnost}

Tokom samih ratnih dešavanja, mnogi ispitanici prijavljuju doživljaj apsurdnosti i nerealnosti. Prizore i doživljaje opisuju kao nejasne, neverovatne, nemoguće, filmske, perverzne, čudne. Osećali su se kao da su „u nekom ludom filmu“ (Govore žene, 127); sve što su iskusili im je bilo 
„kao neki čudni ružni san“, koji oni nisu mogli adekvatno da obrade i razumeju (Sudbine civila 1, 91). Rat je „,̌udo“ (Ratovanja 1, 145); život pod ratom je „potpuno novi svemir“, „druga dimenzija“" (Ratovanja 2, 39-40). Navode da je tokom rata život bio ,intenzivniji“, verovatno „zbog toga daha smrti koji se osjećao za vratom“ (Ratovanja 2, 21). Percepcija vremena je bila drugačija; vreme bi ,prolazilo, nekad prâvo sporo, nekad užasno brzo“ (Ratovanja 2, 119). Neki - suprotno - život u ratu opisuju kao jednoličan: „To što se tad dešavalo i što smo tad osjećali uopšte nije u sferi nekih normalnih osjećanja [...] Ja sam se osjećao bolesno na neki način“ (Sudbine civila, 27); „Rat je jedno beskrajno čekanje“ (Ratovanja 3, 101).

Pored apsurdnosti iskustava, ispitanici ističu i stravičnu surovost i morbidnost događanja, kojom su bili zatečeni. Ratovanje je „kao da svaki dan ideš na sahranu“ (Ratovanja 3, 107).

\subsection{Tema: Preovlađujuće emocije i problemi sa mentalnim zdravljem}

U odgovorima ispitanika se može uočiti čitav spektar emotivnih stanja koja navode da su doživljavali tokom rata - od straha, strepnje, zabrinutosti, zebnje, panike, prestravljenosti, izbezumljenosti, šokiranosti, potresenosti, napetosti, iščekivanja i opreznosti, kao i tuge, melanholije, nostalgije, očajanja, depresivnosti, usamljenosti, napuštenosti, poniženosti i osramoćenosti, preko griže savesti i kajanja, kao i ljutnje, besa, prkosa i frustriranosti, pa sve do bezizlaznosti, zasićenosti, demotivisanosti, ali i nade. Neki ispitanici navode i da su im emocije bile utrnule: „U ratu je čovjek u grču [...] Tek nakon nekog vremena dolazi do te eksplozije unutar čovjeka, kad stvarno osjeti onu pravu tugu i žal“" (Ratovanja 2, 27).

Ispitanici opisuju neke strategije koje su im pomagale da prevladaju negativne emocije i stres - pomagalo im je da strogo strukturišu svoj dan; da budu okupirani fizičkim aktivnostima (kao što je kuvanje, heklanje, čišćenje oružja) i mentalnim aktivnostima (kao što je čitanje, učenje); da zbijaju šale; da razgovaraju sa bliskim osobama. Neki ispitanici su se tokom rata više okrenuli religiji. Ponekad ističu da im je tokom rata za ponovno uspostavljanje „,normalnosti“" značilo da mogu da idu u školu ili na posao, da mogu da se zaljube. S druge strane, neki ispitanici navode da im je teško 
padalo što nisu imali nekoga kome će se poveriti i nekoga ko će ih saslušati, kao i to što su u izbeglištvu nailazili na nerazumevanje. Pred saborcima bi osećali da moraju da skrivaju znake straha i sumnje, a pred decom da moraju da prestaju da plaču. Neki ispitanici navode da su tokom rata počeli da (zlo)upotrebljavaju supstance poput cigareta, marihuane i alkohola.

Tokom rata, ispitanici navode da su iskusili simptome koji uključuju gubitak apetita, nekontrolisano plakanje ili smejanje, preterano spavanje, tremor. Čak i godinama nakon rata, neki učesnici rata prijavljuju simptome posttraumatskog stresnog poremećaja, koji se može razviti kod osoba koje su bile izložene životno ugrožavajućim iskustvima. U analiziranim intervjuima, takvi simptomi obuhvataju intruzivna i uznemirujuća prisećanja, uznemirujuće snove, ponovna doživljavanja događaja (flashbacks), iritabilnost i ispoljavanja ljutnje. Ovakvi simptomi se mogu javiti kada neka draž iz spoljašnje sredine (npr. slika, miris ili zvuk) podseti ispitanika na traumatski događaj.

Upravo kada je reč o pamćenju, učesnici u ratu pominju iskustva koja su im ostala „urezana“, koja su im ostavila „psihički žig“ (Ratovanja 1, 7), „debelog traga“ (Ratovanja 2, 40), „životne ožiljke“ (Ratovanja 3, 84).

\subsection{Tema: Usmerenost na druge osobe}

Ispitanici često pominju članove svoje uže i šire porodice, prijatelje, saborce. Tokom rata su se naročito starali za dobrobit svojih roditelja, supružnika i dece. Osećali su zabrinutost i strah da se članovima porodice nešto ne desi i strepeli su kako će oni podneti ako se njima, ispitanicima, nešto desi. U izbeglištvu im je nedostajala porodica i tragali su za načinima da ih kontaktiraju. Neki roditelji navode da su se trudili da zaštite decu od traumatičnih scena: „nisam htjela pustiti u njenu dušu taj užas“ (Govore žene, 107). Porodica je bila ono što je ispitanicima „davalo snagu“.

Ispitanici navode da su kako primali, tako i pružali drugima instrumentalnu i emotivnu podršku; mnogi ljudi su tokom rata bili spremni na preuzimanje velikog ličnog rizika kako bi pomogli bliskim osobama. Vremenom su se kod nekih razvili i saosećanje, empatija i solidarnost prema strancima sa kojima nisu delili religijski ili etnički identitet. U najtežim trenucima se javljala potreba da se nediskriminativno pruži pomoć: 
„Nisam samo ja spontano [...] koji god su osjećali potrebu da pomognu, bez obzira na ime. Tu je bilo i Srba, i Hrvata, i Muslimana. Svi su pomagali“" (Govore žene, 94)

Ispitanici su primećivali i veću koheziju u grupama - ljudi su se držali zajedno i podržavali su jedni druge: ,Jedan za drugoga smo živili, svi smo bili jednaki, kô braća“ (Ratovanja 3, 27); ,Ti nekakvi ljudi [...] koje sam ja prije znao površno, sad smo svi mi bili kao zajednička porodica i familija i svi smo se nekako pazili i brinuli jedno za drugo" (Ratovanja 2, 189).

\subsection{Ostale teme}

U odgovorima ispitanika se mogu uočiti i bazične ljudske potrebe, poput fizioloških potreba (za vodom, hranom, skloništem), potreba za sigurnošću, potreba za pripadanjem, a donekle i potreba za uvažavanjem i potreba za samoostvarenjem.

Ispitanici pominju i dileme, tj. situacije u kojima im je bilo teško da donesu odluku. Bivali su podeljeni između svojih želja i potreba, sa jedne strane, i želja i potreba njima važnih osoba, sa druge strane. Pri pravljenju izbora bi se dvoumili, ,preznojavali“, bivali u „nezgodnoj situaciji“.

Ispitanici često ističu da im je rat naglo preusmerio ili potpuno prekinuo dotadašnji tok života. Osećali su da im se desio prekid, rez, ,,cut“. Navode da su im takvim radikalnim promenama bili osujećeni školovanje i karijera; da je čitava generacija „stagnirala“ (Ratovanja 3, 20): „Kad razmislim o svom životu prije rata, u ratu i sad, to je stvarno kao tri života“ (Sudbine civila 1, 69).

Većina ispitanika govori i o ličnim promenama. Neki navode da su im tokom rata upoznavanje i razgovor sa osobama drugih nacionalnih, etničkih ili verskih identiteta, kao i drugog socioekonomskog statusa, pomogli da se oslobode predrasuda. Veliki broj ispitanika ističe da su im se nakon rata izmenili pogledi na svet i životne vrednosti - osećaju se zrelije, nemaju više „naivnu sliku sveta“, daju prednost duhovnom nad materijalnom, zahvalniji su za male stvari, prvo se staraju o zadovoljenju osnovnih potreba, dok je sve ostalo „nadgradnja“: ,kad je bilo ono, po dva dana nisi pija vode, pa znaš cjenit ovu čašu vode kad uzimaš“ (Ratovanja 3, 17); „živim sad život koji sam dobio kao bonus“" (Ratovanja 1, 66). 


\section{Zaključak}

Čovek je svesno, samostalno biće, različito od svih drugih, čak i od braće i sestara jednojajčanih blizanaca. Istovremeno, čovek je biće ukotvljeno u svoje vreme, kulturu, naciju, i brojne grupe kojima pripada i sa kojima delimično deli pogled na svet. Nakon velikih sukoba i stradanja, grupe vrše pritisak da oblikuju istoriju po svojoj potrebi i da uniformišu sećanja pojedinaca tako da najbolje služe interesima najmoćnijih. Međutim, ove lične istorije najrazličitijih ljudi iz Srbije, Hrvatske i Bosne i Hercegovine, sa potpuno različitim ratnim iskustvima i traumama, svedoče da iza svake velike istorije stoji niz malih ljudskih priča, koje sa tim silnicama istorije ne moraju da imaju, i često nemaju, mnogo toga zajedničkog. Ali zato kroz slušanje ili čitanje tih intimnih ispovesti obični ljudi sa svih strana mogu da se prepoznaju i susretnu, razumeju da nisu sami i da „ima i drugih nego ti koji nepoznati od tebe žive tvojim životom“, kako je to približio Tin Ujević, koji je sa sva tri ova naroda živeo, pio, radovao se, patio i pisao poeziju.

\section{Literatura}

Baker, K.M. (1985). Memory and practice: Politics and the representation of the past in eighteenth-century France. ,Representations“ 11, str. 134-164.

Bar-Tal, D. (2000). Shared beliefs in a society: Social psychological analysis. Thousand Oaks, CA, US: Sage Publications, Inc.

Bar-Tal, D., Rosen, Y. (2009). Peace education in societies involved in intractable conflicts: Direct and indirect models. „Review of Educational Research“ 79(2), str. 557-575.

Bartlett, F.C. (1932). Remembering: A study in experimental and social psychology. Cambridge, England: Cambridge University Press.

Boraine, A. (2000). A country unmasked: Inside South Africa's Truth and Reconciliation Commission. Oxford: Oxford University Press.

Cairns, E., Roe, M.D. (eds.). (2003). Memories in conflict. London: Macmillan.

Cakal, H., Petrović, N. (2017). Intergroup contact and ingroup identification as predictors of intergroup attitudes and forgiveness in the Serbian context: The moderating role of exposure to positive information. „Primenjena psihologija“ 10(4), str. 477-497.

Ebbinghaus, H. (1913). Memory. Trans. H.A. Ruger, C.E. Bussenius. New York: Teachers College [Original work published 1885]. 
Gojković, D. (2005). Ljudi u ratu: Govore žene: Ne bilo ga nikad i nigdje. Beograd: Dokumentacioni centar Ratovi 1991-1999.

Gojković, D., Bašić, N., Delić, V. (ur.). (2003). Ljudi u ratu: Sudbine civila 1. Beograd: Dokumentacioni centar Ratovi 1991-1999.

Gojković, D., Bašić, N., Delić, V. (ur.). (2004). Ljudi u ratu: Ratovanja 2. Beograd: Dokumentacioni centar Ratovi 1991-1999.

Gojković, D., Bašić, N. (ur.). (2004a). Ljudi u ratu: Ratovanja 1. Beograd: Dokumentacioni centar Ratovi 1991-1999.

Gojković, D., Bašić, N. (ur.). (2004b). Ljudi u ratu: Ratovanja 3. Beograd: Dokumentacioni centar Ratovi 1991-1999.

Halbwachs, M. (1980). The collective memory. New York: Harper Colophon.

Kostovicova, D. (2016). Seeking justice in a divided region: Text analysis of regional civil society deliberations in the Balkans. „International Journal of Transitional Justice“ 11(1), str. 154-175.

Kunda, Z. (1990). The case for motivated reasoning. „Psychological Bulletin“ 108(3), str. $480-498$.

László, J. (2013). Historical tales and national identity: An introduction to narrative social psychology. London: Routledge.

Loftus, E.F. (1979). The malleability of human memory: Information introduced after we view an incident can transform memory. „American Scientist“ 67(3), str. 312320.

Neisser, U. (ed.). (1982). Memory observed: Remembering in natural contexts. New York: W.H. Freeman.

Petrović, N. (2007). Kolektivna sećanja i perspektive poslekonfliktne modernizacije. U: T. Cipek, O. Milosavljević, 1918: Kultura sjećanja: Povijesni lomovi i svladavanje prošlosti. Zagreb: Disput.

Pettigrew, T.F., Tropp, L.R. (2006). A meta-analytic test of intergroup contact theory. „Journal of Personality and Social Psychology“ 90(5), str. 751-783.

Petty, R.E., Cacioppo, J.T. (1986). Communication and persuasion. New York: Springer.

Tajfel, H., Turner, J.C. (1986). The social identity theory of intergroup behavior. U: S. Worchel, W.G. Austin (eds.), Psychology of intergroup relations. Chicago: Nelson-Hall, str. 7-24.

Truth and Reconciliation Commission of South Africa Report. (1998). Vol. 1-5. Cape Town: TRC. 